\title{
REENGINEERING OF BUSINESS PROCESSES IN CORPORATE GOVERNANCE OF UKRAINIAN AGRICULTURAL SECTOR
}

\author{
Tatiana V. Kravchenko \\ Taras Shevshenko National University of Kyiv \\ Andrii S. Kravchenko \\ Carlsberg Ukraine
}

\begin{abstract}
The article reveals a conceptual basis for implementation of business processes reengineering in corporate governance of enterprises of the agricultural sector. The main problems of implementation of corporate forms of organization at enterprises of the agricultural sector of Ukraine have been determined. The recommendations for the effective use of international experience in corporate governance in the agricultural sector have been provided.
\end{abstract}

Key words: agricultural sector, reengineering, corporate governance, business processes, corporation

\section{INTRODUCTION}

The agricultural sector is a basic component of the economy of Ukraine and forms the foundations of social and economic development of the country. Besides sustainable provision of population with quality and affordable products, the national agricultural sector can provide the solution of world problems of agricultural production ensuring.

The active integration into the world economic space, strengthening the globalization processes and European integration require adaptation to new constantly changing conditions.

For the efficient development and operation of enterprises of the agricultural sector, implementation of access to foreign markets it is necessary to use mod- 
ern information technologies that can detect internal resources, attract foreign investments, as well as to hold reengineering business processes of management systems, including corporate ones. The corporate governance in the agricultural sector of Ukraine is a new phenomenon. The result of the state agrarian policy has become the vertical integration leading to the formation of cooperative ties between enterprises of the agricultural sector and food processing industry. In terms of new development conditions there is a problem of their transformation into the enterprise of market type.

The main purpose of the research carried out in this article is a substantiation of theoretical and practical foundations of creation of the effective system of corporate governance in the agricultural sector on the basis of business processes reengineering.

\section{LITERATURE BACKGROUND}

The issue of business processes governance and improvement of their efficiency has being studied both by foreign and national scientists, including Harinhton, Drucker, Beer, Davenport, Sheer, Deming, Ildemenov and others. The main theoretical principles of business processes reengineering were formulated by Hammer and Champi. The famous economists Oyhman and Popov studied the business processes reengineering through the example of reorganization of the leading foreign companies. Rother and Shook focused on identifying of business processes and their analysis, the exact construction and documentation. Robson and Ullah focused on practical aspects of the implementation of business processes reengineering [Pimenova 2013]. As for the management of business process in corporate governance, these issues still remain insufficiently explored. This is what caused the direction of the scientific research.

\section{RESEARCH METHODS}

The methodical basis of the research is the process approach, the dialectical method of cognition, the fundamental position of modern economic theory, the concept of the economy of production and business management. In order to achieve a desired goal the following methods have been used: dialectical, analysis and synthesis - to determine the economic essence of business processes reengineering; statistical analysis and analytical data grouping - to identify the main trends in the corporate governance of the agricultural sector of Ukraine; system analysis - to study existing approaches to reengineering of enterprise business processes and analyzing the international experience of corporate governance at the enterprises of the agricultural sector. 


\section{RESEARCH FINDINGS}

The enterprises of the agricultural sector of Ukraine have greater potential than domestic needs. It can be the basis for development and effective integration of the national economy to world space. But at the moment the agricultural sector of Ukraine requires significant reforms to overcome serious problems.

The following main problems have been determined with the development strategy of the agricultural sector of Ukraine by 2020 [Ministry of Agrarian Policy and Food of Ukraine]:

- uneven development of various business forms (modes) in terms of the midsize manufacturer weakening due to the creation of formally similar, but not equal economic conditions for economic entities of different size and social burden;

- lack of regulatory framework and absence of motivation for cooperation and consolidation of small agricultural producers within the rural community, low marketability of production, weakening of economic basis of rural communities;

- unstable competitive position of domestic agricultural and food products on international markets because of the uncompleted process of adaptation to European standards of quality and safety of agricultural and food products;

- low rates of technical and technological renewal of production;

- risks of production costs increasing due to the increase of equipment deterioration, the prevalence of the use of outdated technologies, the increasing cost of non-renewable natural resources in cost structure;

- significant loss of production due to the imperfections of agricultural market infrastructure, storage logistics;

- absence of motivation of producers to comply with the requirements of agroecological production;

- limited capacity of the internal market of agricultural and food products, caused by the low payment ability of the population;

- lack of the efficiency of self-organization and self-regulation of the market of agricultural and food products, difficulty in developing a consolidated position of agricultural producers to protect their interests;

- lack of awareness of a large part of agricultural producers of market conditions and business environment in the industry;

- incompleteness of land reform.

Analysis of problems allowed making conclusions about the need for serious reforms in the agricultural sector. The answer to the high dynamics of the environment and the need for a mobile and flexible structure of interaction between enterprises of the agricultural sector can be a method of business processes reengineering. Business processes reengineering or corporation reengineering based 
on business processes is a common revolutionary way of organizational restructuring. Hammer and Champy offered the following definition: "reengineering is the fundamental reinterpretation and radical redesign of business processes to achieve significant improvements in such key indicators for the modern business performance as costs, quality, service level and efficiency [1993]. Business process reengineering cycle is presented in Figure 1.

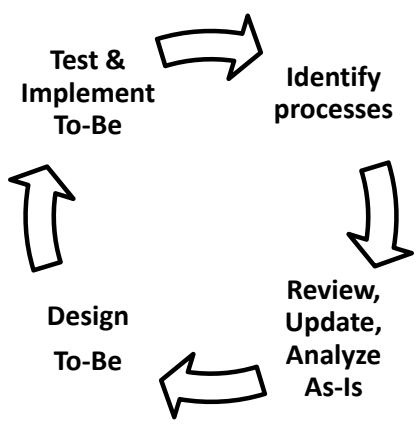

FIGURE 1. Business process reengineering cycle

Source: ROTHER M., SHOOK J. 1999: Learning to see. Lean Enterprise Institute, Cambridge, MA.

The reengineering in corporate governance acquires particular importance in the development of the agricultural sector. This will increase the efficiency of the enterprises of the agricultural sector and ensure food security of the country. In modern conditions most enterprises of processing sector are integrated with the agricultural producers to ensure constant high-quality raw materials provision. However, the integration is not always carried out on mutually beneficial conditions and enterprises are not always ready for it because of the lack of mobility and flexibility in the structure of management and production.

In recent years, an amalgamation of agricultural enterprises and other economic units that vary in terms of membership and corporate objective has been observed in the agricultural sector. However, the most common forms of agricultural business in all climatic regions of Ukraine are private enterprises and limited liability companies [Mazuryk 2006, s. 265-268].

The reengineering method is based on the principle that all business processes redesign will optimize the integration processes taking into account the targeted interests of all participants of the integrated system. Besides reengineering is efficiently used for crisis overcoming by the enterprise. This type of change radically rebuilds business processes which do not meet modern requirements.

The main directions of the reengineering in corporate governance of the agricultural sector enterprises is to create conditions for restructuring of agricultural enterprises into joint stock companies and integration processes. This type of transformations increases investment opportunities in the agricultural sector. The 
legislation of Ukraine provides almost the only way to privatization of enterprises of the agricultural sector - their restructuring into public joint stock companies. Joint-stock company is a specific form of entrepreneurial activity and may be set up in all areas where there is a need for equity capital raising. The main problem of transformation of enterprises into joint stock companies is to create a mechanism for the movement of equity assets that allows the owner to dispose of part of the property and land which he owns, in its sole discretion. Integration processes in the agricultural sector of the economy of Ukraine may be implemented primarily through: the participation of agricultural producers in horizontal integration, participation in vertical integration, in cooperation and corporatization.

The following factors may refer to the main restraining ones in creation of such a mechanism in Ukraine:

- dependence of the agricultural sector on government regulation;

- absence of securities market in the agricultural sector and unfinished proc-

ess of shares consolidation;

- absence of land market;

- inconsistency of the legal and regulatory framework;

- provision of reformed farms with the benefits of private corporations, which limits the number of potential owners usually by its members;

- immaturity of the stock market.

Comparative characteristics of the agricultural potential and its usage efficiency in Ukraine and the European Union are presented in Table 1.

TABLE 1. The agricultural potential and efficiency of its use in Ukraine and the European Union in 2005 and 2015

\begin{tabular}{|l|c|c|c|c|}
\hline \multirow{2}{*}{ Indicator } & \multicolumn{2}{|c|}{ Ukraine } & \multicolumn{2}{c|}{$\begin{array}{c}\text { European Union } \\
\text { (28 countries) }\end{array}$} \\
\cline { 2 - 5 } & 2005 & 2015 & 2005 & 2015 \\
\hline Population, mln. people & 47.3 & 42.9 & 461.4 & 510.4 \\
\hline Rural population, mln. people & 15.3 & 13.3 & 109.3 & 112.9 \\
\hline The proportion of rural population,\% & 32.3 & 31 & 23.7 & 22.1 \\
\hline Area agricultural lands mln. hectare & 41.7 & 42.7 & 168.6 & 174.4 \\
\hline Proportion of agriculture in GDP,\% & 9.9 & 11.9 & 2 & 2.5 \\
\hline Proportion of of employment in agriculture, \% & 19.2 & 17.5 & 4.3 & 18.3 \\
\hline $\begin{array}{l}\text { Gross value added of Agriculture 1000 ha of } \\
\text { agricultural lands, thous. Euro }\end{array}$ & 158 & 184 & 849 & 1456 \\
\hline $\begin{array}{l}\text { Gross value added agriculture for 1 employed, } \\
\text { thousand. Euro }\end{array}$ & 1.6 & 2.74 & 23.2 & 64 \\
\hline $\begin{array}{l}\text { Labour productivity of agriculture per } \\
\text { 1 employed, thousand. Euro }\end{array}$ & 7.3 & 8.6 & 14.1 & 17.3 \\
\hline
\end{tabular}

Source: Compiled by the author according to ec.europa.eu/eurostat and www.ukrstat.gov.ua/ 
The analysis shows that the efficiency of the agricultural potential of Ukraine is much lower, that is why we will consider international experience in the agricultural sector to develop the reengineering mechanism in corporate governance of enterprises of the agricultural sector.

The experience of cooperation and corporatization of the USA can be useful for restructuring of the agricultural industry of countries passing through the stage of market transformation, including Ukraine. The USA agricultural corporation is first of all joint stock companies relevant to the Ukrainian limited liability companies. At the same time partnership as the main form of collective agricultural enterprises plays a significant and constantly growing role in the agricultural sector of the country.

In the last years there has been a tendency in Great Britain of combining the agricultural sector with industrial capital; large formations of agroindustry complexes have been created; concentration of production of certain foods has been practiced. Provision and guarantees of land ownership, rent control and compensation conditions are regulated by the Act on agricultural tenure, adopted in 1990 [Bayura, Romanyuk 2013].

Farmers, land owners and employees participate in the development of agrarian relations in Great Britain. Most frequently a British farm is a family business. The farmers associate in cooperatives. In this country cooperation is carried out in the following main forms:

- credit cooperative and state systems represented by the traditional cooperatives for sales and processing of agricultural products and supplying farms with producers' goods;

- large universal cooperative associations;

- cooperative associations based on vertical and horizontal integration, having national regional importance;

- $\quad$ production cooperatives based on partnership (partnership associations). Group forms of farming occupy a special place in agriculture of France. They have a significant impact on the agricultural production process. The development of group forms is related to deepening of its specialization and concentration processes. The cooperatives take the main place among them.

There are other collective forms of agricultural production, such as the actual societies, civil societies of agricultural production and agricultural producers associations, which provide production and sales of agricultural products of a certain type on a contractual basis. In France agricultural legal relationships are regulated by the Agrarian Code, which specifies the existence of different forms of agricultural tenure, availability of various forms of management of agricultural enterprises, development of rental relations, orientation on large farms [Bayura, Romanyuk 2013]. 
According to the analysis of international experience, the cooperatives prevail in the agricultural sector of foreign countries. The number of 46744 agricultural enterprises presents different organizational and legal forms of business, including 7721 agricultural companies (mainly limited liability companies), 3627 private companies, 596 industrial agricultural cooperatives, 32303 farming enterprises, 241 state enterprises, 2256 enterprises of other business forms operated at the beginning of 2016. The forms and the number of enterprises in the agricultural sector of Ukraine are presented in Table 2.

TABLE 2. The forms and number of enterprises in the agricultural sector of Ukraine in 2012-2015 (units)

\begin{tabular}{|l|c|c|c|c|}
\hline Forms of enterprise & 2012 & 2013 & 2014 & 2015 \\
\hline In total & 47656 & 49848 & 46012 & 46744 \\
\hline By size: & 26 & 27 & 28 & 29 \\
\hline - large & 3143 & 2915 & 2595 & 2533 \\
\hline - medium & 44487 & 46906 & 43389 & 44182 \\
\hline - small By the organizational and the legal forms of business \\
\hline \multicolumn{5}{|c|}{} \\
\hline - business partner-ships & 8235 & 8245 & 7750 & 7721 \\
\hline - private enterprises & 4220 & 4095 & 3772 & 3627 \\
\hline - co-operatives & 848 & 809 & 674 & 596 \\
\hline - private farms & 34035 & 34168 & 33084 & 32303 \\
\hline - state enterprises & 296 & 269 & 228 & 241 \\
\hline - other forms & 22 & 2262 & 504 & 2256 \\
\hline
\end{tabular}

Source: Compiled by the author according to www.ukrstat.gov.ua

The majority of enterprises in the agricultural sector of Ukraine are small private farms. During the period of 2012-2015 the number of cooperatives was decreasing and the number of large enterprises was increasing very slowly. This can be explained by the fact, that the development of the agricultural cooperatives is largely dependent on public administration. The absence of a clear government strategy and its implementation mechanisms in this direction leads to the restraint of the evolutionary progressive transformation of small agricultural producers.

The task of the state is, having understood the advantages and prospects of cooperation from the position of socially important purposes, to create conditions for its development, contribute its first attempts of development, reduce personal expenses of the cooperative movement initiators. The cooperation development will allow solving many problems, without financial support, referring to the sustainable development of rural areas [Ministry of Agrarian Policy and Food of Ukraine]. Moreover, the process of cooperation among small agricultural producers will improve the competitiveness of the agricultural sector of Ukraine. 
In order to solve the defined problems, it is necessary to carry out the reengineering of business processes in the corporate governance of the agricultural sector, which, we believe, should include the union of two or more enterprises inside the corporation. This will improve relationships with suppliers of raw materials, save on transport costs and increase the competitiveness of the agricultural sector of Ukraine.

Since reengineering involves fundamental changes of the outdated management functions and nature of work performed, the state and senior management of the enterprises should initiate and lead the process.

\section{CONCLUSIONS}

The analysis of current state and international experience of corporate governance has led to the conclusion that the development of corporate structures, combining several business entities based on horizontal and vertical integration, that partially or fully consolidate their resources to implement innovative projects (programs), is prospective in the agricultural sector of Ukraine. The purpose of creation of such financial and agricultural groups is ensuring the competitiveness and efficiency of production activities of the agricultural sector, job creation and food security. Using the international experience in corporate governance of enterprises of the agricultural sector and ensuring the conditions for creation of integrated organizational structures (including public joint-stock companies) in Ukraine will promote:

- increasing of investments amount for agrarian reform implementation;

- development of market infrastructure of the agricultural sector;

- increasing of profitability of enterprises of the agricultural sector and efficiency of the agricultural business in general.

Therefore, a prerequisite for the successful development of corporate governance in Ukraine should be the integration of management and use of modern tools, including business processes reengineering.

\section{References}

BAYURA D. O., ROMANYUK V.M. 2013: The Corporate Governance Systems Transformation During the Financial Crisis, Economic Herald of the Donbas, 4(34), p. 156-160.

FYLYUK G.M., PIMENOVA O.V. 2014. State support of agriculture: the analysis of EXPERIENCE OF GERMANY. ZARZĄDZANIE FINANSAMI I RACHUNKOWŚĆ, 2(4), p. 19-30. GAYVORONSKY V.M. 2003: Agrarian Law Ukraine. Right, Kharkov. 
HAMMER M., CHAMPY J. 1993: Re-engineering the Corporation: A Manifesto for Business Revolution. Nicholas Brealey Publishing, London.

MAZURYK S. M. 2006: The development of the corporate sector agricultural pidpryyemstv, SM Mazuryk, Proceedings of the fifth plenum of the Union of Economists of Ukraine and international nauk. and practical. Conference Corporate Governance in Ukraine: management, finance, audit, p. 265-268.

ROTHER M., SHOOK J. 1999: Learning to see. Lean Enterprise Institute, Cambridge, MA. Ministry of Agrarian Policy and Food of Ukraine database [Electronic source], 2016. minagro.gov.ua

MOLDOVAN L. V. 2012: Socio-economic nature of agricultural enterprises, Innovative transformation of agricultural sector, Institute of Economics and Forecasting, p. 235-250. PIMENOVA O. V. 2013: Institutional maintenance of forms of economy in the system of agrarian relationship. Dis. PhD; Taras Shevchenko National University of Kyiv, Kyiv. http://ec.europa.eu/eurostat http://www.ukrstat.gov.ua/ 